\title{
Corporate Tax Avoidance of Malaysian Public Listed Companies: A Multi-Measure Analysis
}

\author{
Nirmala Devi Mohanadas ${ }^{*}$, Abdullah Sallehhuddin Abdullah Salim², Suganthi Ramasamy ${ }^{1}$ \\ ${ }^{1}$ Faculty of Business, Multimedia University, 75450 Air Keroh, Melaka, Malaysia. \\ ${ }^{2}$ Faculty of Management, Multimedia University, Persiaran Multimedia, 63100 Cyberjaya, Selangor, Malaysia.
}

\begin{abstract}
Objective - Even with corporate tax avoidance being extensively studied, it is still lacking a single universal measurement. There is also a dearth of studies focusing on developing economies such as Malaysia. This study, therefore, analyses the correlations between effective tax rates (ETRs) and book-tax differences (BTDs), which are the most commonly used measures of corporate tax avoidance on Malaysian listed companies for ten years.

Methodology/Technique - This study performs distribution, frequency, and correlation analyses on the ETRs and BTDs of the Top 300 companies listed in the Main Market of Bursa Malaysia based on market capitalization. The data used spans a ten-year period from 2010 to 2019.

Findings - The results of the distribution, frequency, and correlation analyses show that both these measures are closely related gauges of corporate tax avoidance.

Novelty - The results of this study provide further statistical proof that ETR and BTD measures of corporate tax avoidance are closely related. Its utilization of data from listed companies in Malaysia expands the current body of literature by addressing corporate tax avoidance practice in a developing economy. By concentrating on both ETR and BTD measures, this study's analysis is consistent with the broad continuum of corporate tax avoidance spectrum and significantly reduces the risk of warping its determination of tax avoidance level.
\end{abstract}

Type of Paper: Empirical study.

JEL Classification: G30, H25, H26, M40.

Keywords: Cash ETR; corporate tax avoidance; GAAP ETR; permanent BDT; total BTD.

Reference to this paper should be referred to as follows: Mohanadas, N.D; Salim, A.S.A; Ramasamy, S. (2021). Corporate Tax Avoidance of Malaysian Public Listed Companies: A Multi-Measure Analysis, Acc. Fin. Review, 6(1), 44 - 53. https://doi.org/10.35609/afr.2021.6.1(1)

\section{Introduction}

As a field of research, corporate tax avoidance has been enjoying ceaseless attention among researchers. However, its empirical aspect is still challenged by the lack of a single universal measure of corporate tax avoidance. There are two main sources of corporate tax information, i.e., financial statements and tax returns.

\footnotetext{
* Paper info: Revised: March 28, 2021

Accepted: June 30, 2021

* Corresponding author: Nirmala Devi Mohanadas

E-mail: nirmala.devi@mmu.edu.my

Affiliation: Faculty of Business, Multimedia University, Malaysia.
} 
While financial statements are publicly accessible, tax returns are confidential and hardly ever shared with outsiders (Hanlon \& Heitzman, 2010; Salihu et al., 2013; Gebhart, 2017). Consequently, most empirical studies have had to rely on the information contained in financial statements to develop their own proxy measures of corporate tax avoidance, such as effective tax rate (ETR) and book-tax difference (BTD) (Hanlon \& Heitzman, 2010). Nevertheless, as these proxies are different from each other, they possess their own advantages and limitations. Besides, the ready access to data in the financial statements allows researchers considerable freedom to construct their own variants of ETR and BTD measures leading to the presence of numerous such measures in the current body of literature. This can eventually cause confusions to researchers in choosing the most suitable measure for their corporate tax avoidance studies. Thus, there is an urgent need for a universally accepted measure of corporate tax avoidance.

However, the creation and adoption of a universallyaccepted measures of corporate tax avoidance is quite challenging to be achieved overnight. Moreover, the correlation between ETR and BTD as yardsticks to corporate tax avoidance is still a grey area because a majority of these studies had been mutually exclusive in employing these measures. Hence, more statistical analyses need to be undertaken on how close these measures are to gauging corporate tax avoidance level.

Meanwhile, the mainstream corporate tax avoidance studies have concentrated mostly on developed economies like the United States, United Kingdom, and Australia. It consequently creates a scarcity of such studies on companies in developing countries such as Malaysia (Salihu et al., 2015). Though not as abundant in numbers, published studies on corporate tax avoidance among Malaysian public listed companies had nearly all used variations of ETR measure. Their mutually exclusive application of ETR measure may negatively impact their ability to capture tax-deferring corporate strategies (Hanlon \& Heitzman, 2010). It heightens the risk of their results being potentially distorted and led to the making of flawed conclusions.

Given the above gaps, this study seeks to examine how closely related the ETR and BTD measures are by measuring the corporate tax avoidance level of Malaysian public listed companies from 2010 until 2019. The structure of this paper is as follows: Section 2 discusses ETRs and BTDs as the corporate tax avoidance measures commonly used in the literature. Section 3 details the methodology adopted by this study in performing its analysis. Section 4 discusses the results of the analysis and Section 5 concludes this study.

\section{Literature Review}

Corporate tax avoidance measure is highly influenced by the source of information used to compute it (Hanlon \& Heitzman, 2010; Salihu et al., 2013). There are two main sources from which such necessary information can be obtained. The first source is tax returns, in which companies report their taxable income and tax payable to the authorities annually. The utilization of tax returns information gives an edge to studies as it allows them to gauge the actual corporate tax burden. Yet, access to tax returns is very much restricted due to its confidential nature. As a result, studies have had to develop proxy measures of corporate tax avoidance using the information in financial statements (Hanlon, 2005; Salihu et al., 2013). Besides its easy access, the information on corporate tax positions in financial statements can be easily interpreted even by the public, who mostly do not have extensive accounting and taxation knowledge. Furthermore, there are high correlations between the information presented in tax returns and financial statements. This demonstrates the effectiveness of financial statement information to represent actual tax returns data in empirical analyses (Salihu et al., 2013). Therefore, this study chooses to focus on corporate tax avoidance measures developed using financial statement information, where the most common measures are ETR and BTD (Hanlon \& Heitzman, 2010; Niklas Lampeniusa, Terry Shevlin, Arthur Stenzelc, 2021).

ETR, or the percentage of tax incurred against income or cash flow, is the most commonly used corporate tax avoidance measure in extant studies (Gebhart, 2017; Fallan \& Fallan, 2019; Drake et al., 2020). While 
there are several variants of ETR being used in the literature, the most frequently used ones are GAAP ETR and cash ETR. ETR's popularity is much helped by its relative ease of computation and its straightforward interpretations. In essence, a lower ETR value denotes a higher corporate tax avoidance level (Asiri et al., 2020). In addition, ETRs can be conveniently compared against the statutory tax rate (STR) to examine whether the company in question has been incurring taxes as mandated by law. Hence, the ease of interpreting ETRs makes them more popular among ordinary public with limited accounting knowledge, especially the shareholders (F. Todd DeZoort, Troy J. Pollard, 2018; Rudyanto \& Pirzada, 2020). Besides these advantages, ETRs can effectively capture vital parts of tax-avoidant strategies employed by companies since such strategies, on the whole, are reflected by the numbers reported in the financial statements (Fallan \& Fallan, 2019). Nevertheless, several studies have opined that the utilization of ETRs as corporate tax avoidance measure is not without limitations. The inherent drawback of ETRs lies in their very use of tax information in financial statements. While the information disclosed in financial statements obey the Generally-Accepted Accounting Principle (GAAP), those reported in tax returns conform to the applicable tax laws and rulings (Hanlon \& Heitzman, 2010). Such computational disparities, particularly between the accounting income in financial statements and taxable income in tax returns, subsequently lead to permanent and temporary tax differences for the companies in future periods. In consequence, they now have to recognize deferred tax in their reporting. Their tax payments in later periods will also consist of current as well as deferred tax expenses (Tan, 2000, p. 393). This consequently will contribute to further distortions when the ETRs are computed.

GAAP ETR, as the elementary form of ETR measure, is the percentage of income tax expense over pretax income. It is named as such due to its usage of GAAP-compliant income tax expense reported in the financial statements (Scott D. Dyreng, Michelle Hanlon, 2008). GAAP ETR measures corporate tax avoidance level by comparing the companies' overall tax burdens to their earnings (Chun Keung Hoi; Qiang Wu; Hao Zhang, 2013; Asiri et al., 2020) Since corporate tax avoidance mechanisms generally involve reducing non-deductible expenses in the financial statements, GAAP ETR is effective in signaling the earnings and tax avoidance strategies practiced by companies (John R. Graham; Michelle Hanlon; Terry Shevlin; Nemit Shroff, 2014; Alexander Edwards, Casey Schwab, 2016; Asiri et al., 2020). However, GAAP ETR also suffers from some limitations. Firstly, the income tax expense figure it uses comprises both the current as well as deferred elements of income tax expense. The problem arises when companies apply tax avoidance strategies that reduce current income tax expense but increase the deferred element (Scott D. Dyreng, Michelle Hanlon, 2008; (Hanlon \& Heitzman, 2010; Salihu et al., 2013; (Gebhart, 2017). On the other hand, some companies practiced non-conforming tax avoidance mechanisms merely to reduce their taxable income but not their accounting income (Hanlon \& Heitzman, 2010; Badertscher et al., 2015;Gebhart, 2017). As a result, GAAP ETR is no longer an effective measure of corporate tax avoidance in any of these situations.

As a complement to GAAP ETR, cash ETR measures the level of corporate tax avoidance by using the actual amount of cash paid out as tax. Through its computation of the percentage of the cash tax paid over pre-tax income, it directly analyzes the usefulness of corporate tax avoidance strategies in reducing cash outflows (Taylor \& Richardson, 2014). In addition, its use of information on actual cash taxes paid avoids the impact of permanent and temporary corporate tax avoidance strategies by Noor et al., (2010). Thus, it reduces the distortion effect of the deferred tax expense element which is present in GAAP ETR (Chun Keung Hoi; Qiang Wu; Hao Zhang, 2013; Watson, 2015). Besides, cash ETR efficiently coalesces corporate practices of tax rate and tax base avoidances (Lampenius et al., 2021). Lampenius et al. (2021) described corporate tax rate avoidance as companies relocating their operations to jurisdictions with lower statutory tax rate to ease their tax burdens. Meanwhile, corporate tax base avoidance refers to the companies' reduction of their taxable income to lower their explicit income tax (Lampenius, et al., 2021). Yet, Lampenius et al. (2021) did note that cash ETR did not distinguish between these corporate tax avoidance strategies. Further shortcomings of cash ETR has also been discussed in other studies. Concerns have been raised that while pre- 
tax income as the denominator of this measure is specific to a particular year, the cash income tax paid which is numerator may contain payments for another year (Scott D. Dyreng, Michelle Hanlon, 2008; (Hanlon \& Heitzman, 2010; (Watson, 2015; Gebhart, 2017). Consequently, the disparity concerning the time may lead to the integrity of the measure being jeopardized. Likewise, akin to GAAP ETR, cash ETR is subject to the inherent issues of employing GAAP-based tax figures over the actual tax figures to measure the level of corporate tax avoidance (Gebhart, 2017).

In response to the limitations of ETR measures, BTD has become widely used as an alternative corporate tax avoidance measure. BTD addresses the weakness of ETR as it represents the difference between the GAAP-conforming accounting income in financial statements and the legally compliant taxable income in tax returns (Desai \& Dharmapala, 2006; Choi et al., 2020). In particular, BTD focuses on the persistent dissimilarities between these incomes. (Desai \& Dharmapala, 2006) and (Choi et al., 2020) contributed the discrepancies between incomes to the companies exploiting the flexibility given in GAAP reporting standards to manipulate their accounting earnings without inflating taxable income. As a result, BTD can capture non-conforming tax avoidance schemes by companies, unlike ETR (Hanlon \& Heitzman, 2010; Gebhart, 2017). Accordingly, a positive BTD value indicates a greater level of corporate tax avoidance (Mary Margaret Frank, Luann J. Lynch, 2009; Khurana et al., 2018). While several studies have found that corporate tax sheltering activities did influence BTD [e.g., (Ryan J. Wilson, 2009), (Tang \& Firth, 2011), (Wilson, Bradley Blaylock, Terry Shevlin, 2012), and (David A. Guenther; Linda K. Krull; Brian M. Williams, 2020)], there are also cautions on the susceptibility of BTD to corporate earnings management instead [e.g., (Hanlon, 2005) and (Tang \& Firth, 2011), (Wilson, Bradley Blaylock, Terry Shevlin, 2012), and (David A. Guenther; Linda K. Krull; Brian M. Williams, 2020)]. Therefore, researchers must exercise a certain degree of circumspection when analyzing corporate tax avoidance using BTD (Derashid \& Zhang, 2003).

Oftentimes, corporate accounting income and taxable income are unlike one another due to the timing and permanent differences arising from the respective reporting processes. Timing difference results from the application of the current period's accounting incomes and expenses to ascertain taxable income for a different period. Permanent difference meanwhile comes from using certain incomes and expenses to compute accounting income but not taxable income, and vice versa (Tran FTIA \& Yu, 2008). BTD incorporates both differences through its variants of total BTD and permanent BTD. Indeed, the combined application of both BTD measures has been advocated by studies to eliminate the risk of overlooking any potential tax effect of managerial actions, be it temporary or permanent difference (Noga \& Schnader, 2013).

Total BTD represents the overall tax difference between accounting and taxable incomes. It embraces the timing as well as permanent differences arising from corporate accounting and tax reporting processes (Lisowsky et al., 2013; Noga \& Schnader, 2013). (Mary Margaret Frank, Luann J. Lynch, 2009) had particularly championed the efficacy of total BTD in measuring corporate tax avoidance, considering that companies with relatively successful tax avoidance schemes would conserve considerable temporary or permanent differences between their accounting and taxable incomes. Nonetheless, its very ability to espouse both timing and permanent differences put total BTD at risk of producing distorted corporate tax avoidance measure as it may include permanent difference caused by earnings management instead of tax avoidance strategies by companies (Desai \& Dharmapala, 2006; Hanlon \& Heitzman, 2010). On the other hand, permanent BTD assesses the deviation between accounting and taxable incomes with regards to only permanent difference. It denotes a company's potentially aggressive tax management approach as permanent difference decreases corporate tax liability while enhancing the accounting income (Lisowsky et al., 2013; Noga \& Schnader, 2013). Thus, its exclusion of temporary difference provides this measure with significant control for corporate earnings management (Mary Margaret Frank, Luann J. Lynch, 2009). Yet, the exclusion of temporary difference has generated criticism towards permanent BTD by Noor et al., (2010). In particular, (Hanlon \& Heitzman, 2010) had highlighted the permanent BTD's substantial omission of corporate tax 
avoidance strategies since it is unavoidable that any corporate tax avoidance strategy would produce a temporary difference.(Mahenthiran S. \& Kasipillai, 2012)

The above discussions indicate that even as both ETR and BTD measures depend on the financial statement information and are equally popular among researchers of corporate tax avoidance, they indeed possess their advantages and disadvantages. Hence, it is prudent for researchers to carefully evaluate these measures and ensure that their selection suits their research objectives. Nonetheless, the correlation between ETR and BTD as yardsticks to corporate tax avoidance is still a grey area since the majority of these studies had been mutually exclusive in employing these measures. In addition, their examinations had used data of firms in developed countries (Hanlon \& Heitzman, 2010; Lisowsky et al., 2013; Gebhart, 2017). Taking this into consideration, this study thus analyzes the tax avoidance level of Malaysian listed companies using ETR and BTD measures to evaluate any correlations between them in the context of a developing economy.

\section{Research Methodology}

In evaluating the level of correlation between ETR and BTD measures, this study performs three types of statistical analysis. The first analysis is the distributional analysis. It provides the main summary statistics of both measures. Frequency analysis, which is the second analysis, looks into the mean trends over time. As the final analysis, Pearson correlation presents statistical validation on the relationship between these measures.

Consistent with its earlier discussions in the literature review, this study utilizes the most frequently used ETRs and BTDs measures of corporate tax avoidance level. The ETR measures used are GAAP ETR (GETR) [(income tax expense/ pre-tax income) x 100] and cash ETR (CETR) [(cash income tax paid/pre-tax income) $x$ 100]. The BTD measures employed are total BTD (TBTD) \{[pre-tax income - (current income tax expense/STR)]/lagged total assets $\}$ and permanent BTD (PBTD) $\{[$ TBTD - (deferred tax expense/STR)]/lagged total assets \}.

Consistent with its focus on the corporate tax avoidance practice in the developing economy of Malaysia, this study concentrates on the Top 300 companies listed in the Main Market of Bursa Malaysia based on market capitalization from 2010 to 2019. The ten-year period ensures that the corporate tax avoidance trend can be properly observed, especially in the ways ETR and BTD measures evolve over time. Moreover, an extensive test period helps to minimize missing data occurrences and provide a sizable sample size. All data are obtained from the Bloomberg® Professional database. The initial sample is filtered to remove foreign companies to avoid the impact of different tax laws application and rates on the analysis. Similarly, companies with net operating loss are eliminated as tax-saving effects from such loss can distort the corporate tax avoidance level. Also excluded are firm-years with missing data as no measure can be derived from them and those with ETR values outside the range of $0 \%$ to $100 \%$ to avoid from model estimation quandary due to the outliers. This study's final sample size consists of 1,012 firm-years in total.

\section{Results}

\subsection{Distributional Analysis}

Table 1 presents the distributional analysis of the ETR and BTD measures. The means of GETR and CETR are lower than the statutory tax rates (STRs) applicable and demonstrate that on average, the companies had been paying lesser tax than legally required. The mean of GETR is also higher than CETR, lending support that GETR captures non-conforming tax avoidance while CETR discloses tax deferral strategies affecting cash flows. Meanwhile, the positive means of TBTD and PBTD shows that on average, the companies' reported book income had been higher than their taxable income. In particular, the mean value of TBTD is higher than PBTD considering that TBTD addresses both permanent and temporary tax 
differences between the companies' accounting and tax reporting practices. Overall, the means of both ETR and BTD measures indicate that the companies had indeed been tax-avoidant during the period tested.

Table 1. Distributional analysis of ETR and BTD measures.

\begin{tabular}{|c|c|c|c|c|c|}
\hline Variable & Firm-years & Mean & Standard deviation & Minimum value & Maximum value \\
\hline GETR & 1,012 & 23.32 & 11.66 & 0.00 & 98.86 \\
\hline CETR & 1,012 & 23.02 & 14.55 & 0.00 & 97.19 \\
\hline TBTD & 1,012 & 1.64 & 5.75 & -17.50 & 66.71 \\
\hline PBTD & 1,012 & 0.36 & 5.40 & -13.92 & 74.90 \\
\hline
\end{tabular}

The standard deviations are quite considerable because of the high variations between the maximum and minimum values. Both GETR and CETR have zero minimum values signifying that there had been companies with no income tax expense at all. The measures' maximum values also show the presence of companies incurring income tax expense higher than the statutory requirement. Comparable results are also displayed for TBTD and PBTD where their respective negative minimum values establish the companies' higher reported book income as compared to taxable income. Their high maximum values also support the presence of companies reporting higher book income against their taxable income.

\subsection{Frequency Analysis}

The mean distributions of ETR and BTD measures over time are presented in the following figures. Figure 1 presents the means between STR, GETR, and CETR over time. The means of GETR and CETR are consistently lower than STR. This supports the observations from the distribution analysis that the companies had been incurring lesser taxes than legally required. However, the mean of CETR is higher than the STR and GETR in 2013. While the differences between means are small, the graph shows that CETR's mean trajectory has been steadily rising since 2010. Besides, the means of both GETR and CETR are higher than the STR in 2018 while the mean of GETR is the highest in 2019. Thus, we infer that the companies had been addressing their deferred taxes in addition to their current income taxes which resulted in higher cash taxes paid during this period. Furthermore, the Malaysian government had implemented a special program for voluntary tax disclosure from November 2018 to September 2019 which might have influenced the companies' cash tax payments and tax avoidance level. 


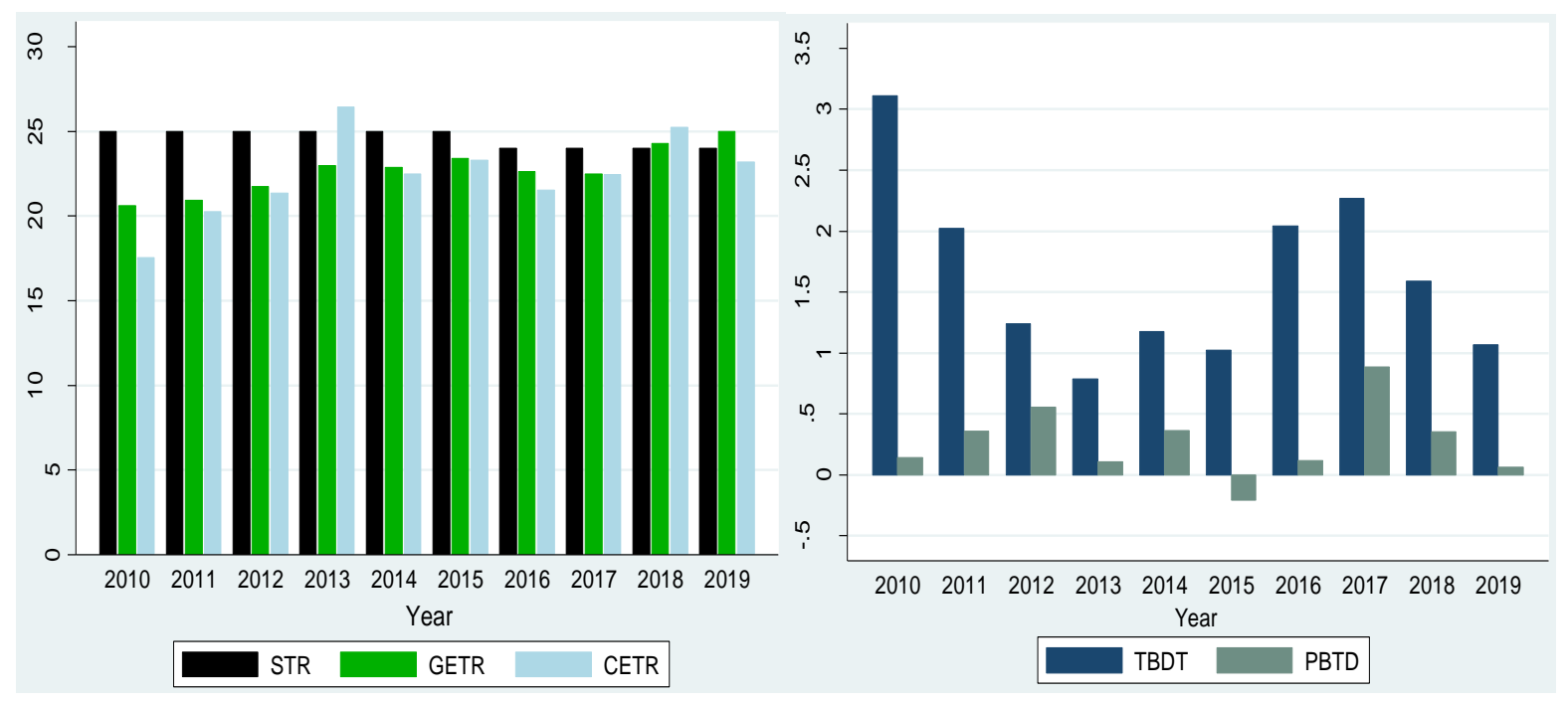

Figure 1. Means of STR, GETR, and CETR. Figure 2. Means of TBTD and PBTD.

Figure 2 demonstrates the mean distributions of TBTD and PBTD over the period tested. The means of TBTD are positive which indicates the companies had been continuously reporting higher book income as compared to taxable income. Similarly, the means of PBTD had been positive for all the years, except in 2015. This shows that over the years, the companies left out more book income and expenses in computing their taxable income thus creating more permanent tax differences in their reported incomes. While the mean of PBTD is negative in 2015, the timing difference present in the companies' reporting is significant enough to cause the mean of TBTD to still be positive.

Figure 3 shows the yearly mean distributions of GETR, CETR, TBTD, and PBTD. The trend comparison demonstrates that any decrease in the means of ETR measures during the years is matched by the rising means of BTD measures. This establishes a correlation between the measures as low ETR values and high BTD values represent an increased level of corporate tax avoidance. As low GETR value shows stronger corporate efforts in tax avoidance through lowering non-tax-deductible expenses in financial statements, the correspondingly high TBDT value indicates that the companies' book income had been greater than their taxable income due to the timing and permanent differences caused by different reporting approaches. Likewise, while low CETR mean value exhibits robust minimization of cash outflows due to temporary and permanent tax differences, the parallel rise in PBTD mean value denotes more aggressive corporate tax avoidance approaches using the permanent difference to enhance book income while reducing taxable income. The results thus corroborate that while ETR measures are more suitable to estimate the less aggressive and legal forms of corporate tax avoidance, BTD measures are better suited for the more aggressive and illegal forms of such practices. 


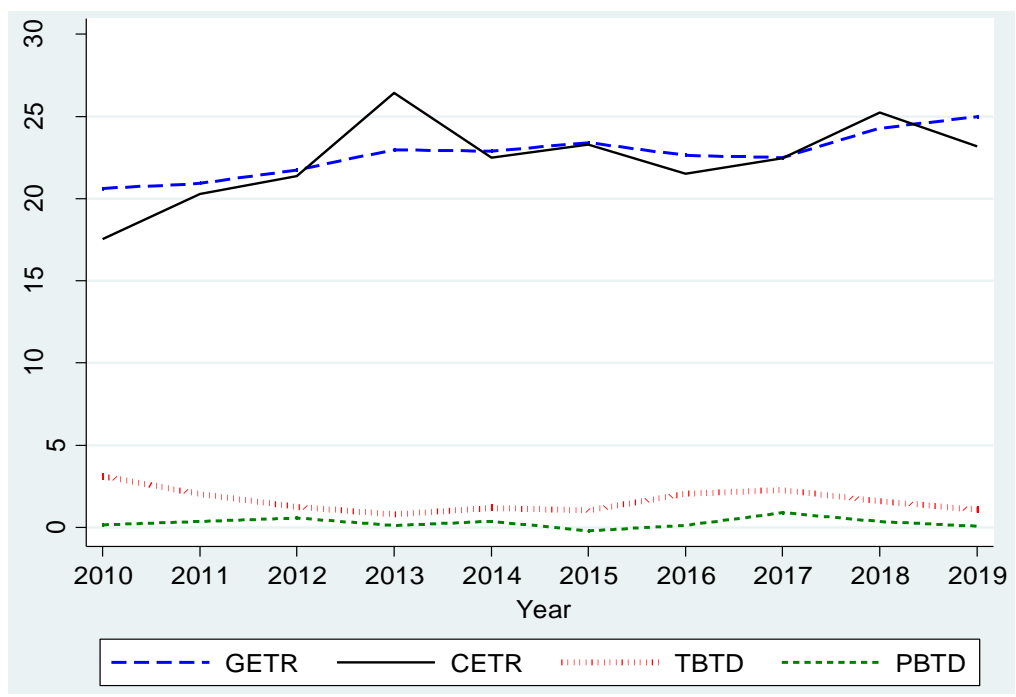

Figure 3. Mean distributions of GETR, CETR, TBTD, and PBTD.

\subsection{Correlation Analysis}

Table 2 presents the Pearson correlation analysis of the ETR and BTD measures. The results show that all measures are significantly related at a $1 \%$ significance level, except between CETR and PBTD. Notably, there are significant positive correlations between GETR and CETR as well as between TBTD and PBTD. This exhibits how corporate tax avoidance measures of similar type are complementary to one another. Meanwhile,

there are significant negative correlations between GETR and both BTD measures whereas CETR has a significantly negative correlation with TBTD. The results further highlight the conforming nature of ETR and BTD measures in gauging corporate tax avoidance level. The mutual coverage by GETR on corporate earnings management and tax avoidance is echoed by TBTD and PBTD which respectively address the differences in the book and taxable income due to the companies' separate reporting practices. This also corroborates the mean distribution patterns in Figure 3 earlier.

Table 2. Pearson correlation analysis of ETR and BTD measures.

\begin{tabular}{|c|c|c|c|c|}
\hline Variable & GETR & CETR & TBTD & PBTD \\
\hline GETR & 1.0000 & & & \\
\hline CETR & $0.6306^{*}$ & 1.0000 & & \\
\hline TBTD & $-0.5750^{*}$ & $-0.5105^{*}$ & 1.0000 & \\
\hline PBTD & $-0.2295^{*}$ & -0.0322 & $0.3645^{*}$ & 1.0000 \\
\hline
\end{tabular}

*Significant at $1 \%$ level.

\section{Conclusion}

The lack of a universal corporate tax avoidance measure has led to studies using several proxies based on financial statement information, the most commonly used being ETR and BTD. Yet, this is quite challenging to achieve overnight. Moreover, the mutually exclusive application of ETR and BTD as corporate tax avoidance measure by a majority of the extant literature has led to the correlation between these measures to still be a grey area. Besides, this study particularly notes that this literature was indeed focusing on companies in developed countries. It creates a dearth of tax avoidance studies on companies operating in developing economies such as Malaysia. However, even with such dearth, nearly all published studies on 
Malaysian listed companies had utilized the ETR measures. Hence, more statistical analyses need to be performed on how close ETR and BTD measures are in gauging corporate tax avoidance level.

In response to the above research gaps, this study examines the correlation between ETR and BTD measures among Malaysian Top 300 public listed companies based on market capitalization for 2010 until 2019. Employing the widely used GETR, CETR, TBTD, and PBTD measures, this study has performed distributional, frequency, and Pearson correlation analyses. The means of these measures show that the companies had indeed been tax-avoidant during the years tested. The frequency analysis on these measures' mean distributions over time also presents a close congruence between them. This is further corroborated by the Pearson correlation analysis. This study thus concludes that both ETR and BTD measures of corporate tax avoidance are closely related.

This study contributes to the extant body of literature by providing further statistical evidence to corroborate the propinquity between ETR and BTD as corporate tax avoidance measures. Furthermore, this study's significance is heightened by its focus on the corporate tax avoidance practice in the little-studied but developing economy of Malaysia. Its use of more recent data covering a longer period also ensures that its analysis addresses the evolvement of corporate tax avoidance over time. By utilizing both ETR and BTD measures, its analysis is consistent with the broad continuum of corporate tax avoidance spectrum. Therefore, this study's application of both ETR and BTD measures significantly reduce the risk of warping its tax avoidance level determination. Thus, its results embody a significantly balanced and thorough empirical analysis.

This study is limited as it utilizes only ETR and BTD measures of corporate tax avoidance. Even though these measures are most commonly used, or traditional, in the literature, several new measurement techniques are being employed nowadays by researchers. In response to this development, this study suggests for future researchers to concentrate on examining the presence of correlations between the traditional ETR as well as BTD measures and other new methods such as (Henry \& Sansing, 2018) HS score, tax shelter score, and unrecognized tax benefits. Besides, this study is also aware that its focus has been only on the Top 300 public listed companies in this country. Consequently, its results may not be representing the other corporate taxpayers in Malaysia. Thus, this study suggests for future studies to incorporate all corporate taxpayers in the country for their analysis.

\section{References}

Adhikari, A., Derashid, C., \& Zhang, H. (2006). Public policy, political connections, and effective tax rates: Longitudinal evidence from Malaysia. Journal of Accounting and Public policy, 25(5), 574-595.

Alexander Edwards, Casey Schwab, T. S. (2016). Financial Constraints and Cash Tax Savings. The Accounting Review, 91(3), 859-881. https://doi.org/https://doi.org/10.2308/accr-51282

Asiri, M., Al-Hadi, A., Taylor, G., \& Duong, L. (2020). Is corporate tax avoidance associated with investment efficiency? North American Journal of Economics and Finance, 52(December 2018), 101143. https://doi.org/10.1016/j.najef.2020.101143

Choi, H., Hu, R., \& Karim, K. (2020). The effect of consistency in book-tax differences on analysts' earnings forecasts: Evidence from forecast accuracy and informativeness. Journal of Accounting and Public Policy, 39(3), 106740. https://doi.org/10.1016/j.jaccpubpol.2020.106740

Chun Keung Hoi; Qiang Wu; Hao Zhang. (2013). Is Corporate Social Responsibility (CSR) Associated with Tax Avoidance? Evidence from Irresponsible CSR Activities. The Accounting Review, 88(6), 2025-2059. https://doi.org/https://doi.org/10.2308/accr-50544

David A. Guenther; Linda K. Krull; Brian M. Williams. (2020). Identifying Different Types of Tax Avoidance: Implications for Empirical Research. Journal of the American Taxation Association, 43(1), $27-50$. https://doi.org/https://doi.org/10.2308/jata-17-044

Derashid, C., \& Zhang, H. (2003). Effective tax rates and the "industrial policy" hypothesis: Evidence from Malaysia. 
Journal of International Accounting, Auditing and Taxation, 12(1), 45-62. https://doi.org/10.1016/S10619518(03)00003-X

Desai, M. A., \& Dharmapala, D. (2006). Corporate tax avoidance and high-powered incentives. Journal of Financial Economics, 79(1), 145-179. https://doi.org/10.1016/j.jfineco.2005.02.002

Drake, K. D., Hamilton, R., \& Lusch, S. J. (2020). Are declining effective tax rates indicative of tax avoidance? Insight from effective tax rate reconciliations. Journal of Accounting and Economics, 70(1), 101317. https://doi.org/10.1016/j.jacceco.2020.101317

F. Todd DeZoort, Troy J. Pollard, E. J. S. (2018). A Study of Perceived Ethicality of Low Corporate Effective Tax Rates. Accounting Horizons, 32(1), 87-104. https://doi.org/https://doi.org/10.2308/acch-51935

Fallan, E., \& Fallan, L. (2019). Corporate tax behaviour and environmental disclosure: Strategic trade-offs across elements of CSR? Scandinavian Journal of Management, 35(3), 101042. https://doi.org/10.1016/j.scaman.2019.02.001

Gebhart, M. S. (2017). Measuring Corporate Tax Avoidance - An Analysis of Different Measures. Junior Management Science, 2(2), 43-60. https://jums.ub.uni-muenchen.de/JMS/article/view/4994/3155

Hanlon, M. (2005). The Persistence and Pricing of Earnings, Accruals, and Cash Flows When Firms Have Large Book- Tax Differences. The Accounting Review, 80(1), 137-166. https://doi.org/https://doi.org/10.2308/accr.2005.80.1.137

Hanlon, M., \& Heitzman, S. (2010). A review of tax research. Journal of Accounting and Economics, 50(2-3), 127178. https://doi.org/10.1016/j.jacceco.2010.09.002

Henry, E., \& Sansing, R. (2018). Corporate tax avoidance: data truncation and loss firms. Review of Accounting Studies, 23(3), 1042-1070. https://doi.org/10.1007/s11142-018-9448-0

John R. Graham; Michelle Hanlon; Terry Shevlin; Nemit Shroff. (2014). Incentives for Tax Planning and Avoidance: Evidence from the Field. The Accounting Review, 89(3), 991-1023. https://doi.org/https://doi.org/10.2308/accr50678

Khurana, I. K., Moser, W. J., \& Raman, K. K. (2018). Tax Avoidance, Managerial Ability, and Investment Efficiency. Abacus, 54(4), 547-575. https://doi.org/10.1111/abac.12142

Lisowsky, P., Robinson, L., \& Schmidt, A. (2013). Do Publicly Disclosed Tax Reserves Tell Us About Privately Disclosed Tax Shelter Activity? Journal of Accounting Research, 51(3), 583-629. https://doi.org/10.1111/joar.12003

Mahenthiran S. \& Kasipillai, J. (2012). Influence of Ownership Structure and Corporate Governance on Effective Tax Rates and Tax Planning: Malaysian Evidence. 27 Austl. Tax F. 941. https://heinonline.org/HOL/LandingPage?handle=hein.journals/austraxrum27\&div=40\&id=\&page=

Mary Margaret Frank, Luann J. Lynch, S. O. R. (2009). Tax Reporting Aggressiveness and Its Relation to Aggressive Financial Reporting. The Accounting Review, 84(2), 467-496. https://meridian.allenpress.com/accountingreview/article-abstract/84/2/467/53299/Tax-Reporting-Aggressiveness-and-Its-Relation-to

Niklas Lampeniusa, Terry Shevlin, Arthur Stenzelc. (2021). Measuring corporate tax rate and tax base avoidance of U.S. Domestic and U.S. multinational firms. Journal of Accounting and Economics. https://doi.org/https://doi.org/10.1016/j.jacceco.2021.101406

Noga, T. J., \& Schnader, A. L. (2013). Book-tax differences as an indicator of financial distress. Accounting Horizons, 27(3), 469-489. https://doi.org/10.2308/acch-50481

Noor, R. M., Fadzillah, N. S. M., \& Mastuki, N. A. (2010). Corporate tax planning: A study on corporate effective tax rates of Malaysian listed companies. International Journal of Trade, Economics and Finance, 1(2), 189.

Tan, L. T. (2000). Financial Accounting and Reporting in Malaysia, Vol. 2.

Rudyanto, A., \& Pirzada, K. (2020). The role of sustainability reporting in shareholder perception of tax avoidance. Social Responsibility Journal, March. https://doi.org/10.1108/SRJ-01-2020-0022

Ryan J. Wilson. (2009). An Examination of Corporate Tax Shelter Participants. The Accounting Review, 84(3), 969999. https://doi.org/https://doi.org/10.2308/accr.2009.84.3.969

Salihu, I. A., Annuar, H. A., \& Sheikh Obid, S. N. (2015). Foreign investors' interests and corporate tax avoidance: Evidence from an emerging economy. Journal of Contemporary Accounting and Economics, 11(2), 138-147. https://doi.org/10.1016/j.jcae.2015.03.001

Salihu, I. A., Obid, S. N. S., \& Annuar, H. A. (2013). Measures of corporate tax avoidance: Empirical evidence from an emerging economy. International Journal of Business and Society, 14(3), 412-427.

Scott D. Dyreng, Michelle Hanlon, E. L. M. (2008). Long- Run Corporate Tax Avoidance. The Accounting Review, 83(1), 61-82. https://doi.org/https://doi.org/10.2308/accr.2008.83.1.61

Tang, T., \& Firth, M. (2011). Can book-tax differences capture earnings management and tax Management? Empirical evidence from China. International Journal of Accounting, 46(2), 175-204. 
https://doi.org/10.1016/j.intacc.2011.04.005

Taylor, G., \& Richardson, G. (2014). Incentives for corporate tax planning and reporting: Empirical evidence from Australia. Journal of Contemporary Accounting and Economics, 10(1), 1-15. https://doi.org/10.1016/j.jcae.2013.11.003

Tran FTIA, A. V, \& Yu, Y. H. (2008). Effective Tax Rates of Corporate Australia and the Book - Tax Income Gap. Australia Tax Forum, 3(September 2008), 233-268.

Watson, L. (2015). Corporate Social Responsibility, Tax Avoidance, and Earnings Performance. Journal of the American Taxation Association, 37(2), 1-21. https://doi.org/https://doi.org/10.2308/atax-51022

Wilson, Bradley Blaylock, Terry Shevlin, R. J. (2012). Tax Avoidance, Large Positive Temporary Book-Tax Differences, and Earnings Persistence. The Accounting Review, 87(1), 91-120.

https://doi.org/https://doi.org/10.2308/accr-10158 